\title{
PENGARUH KARAKTERISTIK PEKERJAAN DAN LINGKUNGAN KERJA FISIK \\ TERHADAP KOMITMEN ORGANISASI DENGAN MOTIVASI KERJA SEBAGAI \\ VARIABEL INTERVENING (STUDI KASUS PADA PEGAWAI KANTOR \\ GUBERNUR PROVINSI NTB)
}

\author{
Ratmaje Syahdan ${ }^{1}$ \\ Siti Nurmayanti ${ }^{2}$ \\ Surati $^{2}$
}

\begin{abstract}
This study aims to determine the effect of Job Characteristics and Physical Work Environment on Organizational Commitment with work motivation as an intervening variable in the employee of the Gubernur Province NTB. The population in this study are civil servants, amounting to 500 employees with a sampling technique that Proportionate Random Sampling totaled 83 civil servants. This type of research is associative causal research. Data collection tool was a questionnaire containing questions about the variables Job Characteristics, Work Environment Physical, Organizational Commitment and work motivation. Data analysis was performed with Path Analysis Model Triming using SPSS. The analysis finds that the job characteristics and significant positive effect on organizational commitment. Job characteristics and significant positive effect on work motivation. Physical work environment positive and significant effect on organizational commitment. Physical work environment positive and significant effect on work motivation. Work motivation positive and significant effect on organizational commitment. Job characteristics and significant positive effect on organizational commitment through work motivation. Physical work environment positive and significant effect on organizational commitment through motivation of employees working in the Office of Gubernur Province NTB.
\end{abstract}

Keywords: Characteristic Employment, Physical Work Environment, Work Motivation and Organizational Commitment.

\section{PENDAHULUAN}

\subsection{Latar Belakang}

Sumberdaya Manusia dalam suatu organisasi mempunyai peranan yang sangat penting, karena Sumberdaya Manusia merupakan penentu penting atas kesuksesan atau kegagalan dari proses perubahan organisasi dan sebagai konsekuensi, perhatian akan sangat ditekankan pada faktor-faktor yang memengaruhi sikap individual terhadap perubahan, salah satunya ditekankan pada faktor-faktor paling penting atas kesuksesan atau kegagalan dari proses perubahan organisasi adalah komitmen mereka pada organisasi (Arnie et.al 2011:1).

\footnotetext{
${ }^{1}$ Mahasiswa MM UNRAM

2 Dosen MM UNRAM
} 


\section{$J M M$ UNRAM \\ JURNAL MAGISTER MANAJEMEN UNIVERSITAS MATARAM \\ Maret 2016}

Pasal 3 UUD RI Tahun 1974 tentang pokok-pokok kepegawaian, menyebutkan bahwa Pegawai Negeri adalah unsur Aparatur Negara, Abdi Negara, dan Abdi Masyarakat yang dengan penuh kesetiaan dan ketaatan kepada Pancasila, UndangUndang Dasar 1945, Negara, dan Pemerintah menyelenggarakan tugas pemerintahan dan pembangunan. Dalam pasal 4, menjelaskan, pada umumnya yang dimaksud dengan kesetiaan dan ketaatan adalah tekad dan kesanggupan untuk melaksanakan dan mengamalkan sesuatu yang disetiai atau ditaati dengan penuh kesadaran dan tanggungjawab.

Menurut Meyer dan Hercovitch (dalam Srimulyani, 2015:9), setiap pegawai memiliki dasar dan tingkah laku yang berbeda berdasarkan komitmen organisasi yang dimilikinya. Robbins (2006:140) menyatakan komitmen pada organisasi merupakan suatu keadaan dimana seorang karyawan memihak pada suatu organisasi dan tujuantujuannya, serta berniat memelihara keanggotaan dalam organisasi itu.

Young et al.1998 (dalam Sopiah, 2008) mengemukakan ada 8 faktor yang berpengaruh terhadap komitmen organisasi yaitu : (1) Kepuasan terhadap Promosi, (2) Karakteristik pekerjaan, (3) Komunikasi, (4) Kepuasan terhadap Kepemimpinan, (5) Pertukaran ekstrinsik, (6) Pertukaran intrinsik, (7) Imbalan ekstrinsik, (8) Imbalan intrinsik. Dari beberapa faktor ini, dapat berpengaruh terhadap komitmen pegawai di dalam organisasi.

Sedangkan Kreitner dan Kinicki, (2005:264), yang menyatakan bahwa dalam istilah umum, dimensi inti pekerjaan adakah karakteristik umum yang ditemukan pada berbagai tingkatan pekerjaan. Dimensi inti dari karakteristik pekerjaan ini selanjutnya digambarkan sebagai berikut: (1). Keanekaragaman keterampilan (skill variety) adalah tingkat sampai dimana pekerjaan $\mathrm{n} \quad 1$ an individu yang mampu melakukan berbagai tugas yang mengharuskanny „gunakan keterampilan dan kemampuan yang berbeda. (2). Indentitas tugas (taks identity) : tingkat sampai dimana suatu pekerjaan membutuhkan penyelesaian dari seluruh proses bagian pekerjaan yang diidentifikasikan. (3). Arti tugas (task significance) adalah tingkat sampai dimana pekerjaan berpengaruh substansial dalam kehidupan atau pekerjaan individu lain. (4). Otonomi (autonomy) : tingkat sampai dimana suatu pekerjaan memberikan kebebasan, kemerdekaanm serta keleluasaan yang substansial untuk individu dalam merencanakan pekerjaan dan menentukan prosedur-prosedur yang akan digunakan untuk menjalankan pekerjaan tersebut. (5).Umpan balik (feedback) adalah tingkat sampai dimana pelaksanaan aktivitas kerja membuat seseorang individu mendapatkan informasi yang jelas dan langsung mengenai keefektifan kerjanya.

Karakteristik pekerjaan merupakan faktor yang dapat memengaruhi komitmen organisasi, dimana pegawai yang merasa puas akan pekerjaannya dan betah untuk bekerja pada organsasi tersebut, maka akan berusaha komitmen terhadap organisasi. Pernyataan tersebut didukung oleh pendapat Steers dan Porter (dalam Purwaningsih, 2008:13) mengemukakan faktor yang memengaruhi komitmen organisasi, antara lain salah satunya adalah karakteristik pekerjaan. Senada dengan pendapat Young et al. (dalam Sopiah, 2008) mengemukakan ada 8 faktor yang secara positif berpengaruh terhadap komitmen organisasional yaitu salah satunya adalah karakteristik pekerjaan. Karakteristik pekerjaan memiliki peran utama meningkatkan komitmen organisasi. Hal ini karena karakterstik pekerjaan dihubungkan dengan kepercayaan mereka terhadap organisasi, maka kepercayaan dapat memberikan pengaruh terhadap komitmen pegawai. 


\section{$J M M$ UNRAM \\ JURNAL MAGISTER MANAJEMEN UNIVERSITAS MATARAM \\ Maret 2016}

Pernyataan dan pendapat ahli tersebut didukung oleh beberapa hasil penelitian, seperti penelitian yang dilakukan oleh Djastuti, Astuti, Subagyo, dan Adriyanto., (2011) terbukti bahwa karakteristik pekerjaan berpengaruh positif dan signifikan terhadap komitmen organisasi.

Pada umumnya pegawai menghendaki tempat bekerja yang cukup terang, udaranya selalu segar dan jam kerjanya tidak terlalu lama. Memberikan tempat kerja yang menyenangkan berarti menimbulkan perasaan yang tidak mudah bosan pada diri pegawai. Hal-hal tersebut dapat berpengaruh secara signifikan terhadap hasil kerja manusia (Wignjosoebroto, 2000). Jika didalam organisasi hal ini tidak bisa diatasi dengan baik, maka dapat merubah perilaku pegawai, dimana setiap pegawai memiliki perilaku yang berbeda berdasarkan komitmen organisasi yang dimilikinya. Dari hal ini lingkungan kerja dapat memengaruhi komitmen pegawai dalam organisasi. Dalam penelitian yang dilakukan oleh Maharani, (2009) bahwa variabel lingkungan kerja berpengaruh terhadap komitmen organisasi. Demikian juga penelitian yang di lakukan oleh Saputra, (2014), membuktikan bahwa lingkungan kerja berpengaruh signifikan terhadap komitmen organisasional.

Selain faktor lingkungan kerja, komitmen organisasi bisa juga dipengaruhi oleh faktor motivasi kerja. Menurut Herzberg (Hasibuan, 1996:109) orang termotivasi melaksanakan pekerjaannya dipengaruhi oleh dua faktor yang merupakan kebutuhan, yaitu (a). Maintenance Factors adalah faktor-faktor pemeliharaan yang berhubungan dengan hakikat manusia yang ingin memperoleh ketentraman badaniah. Kebutuhan kesehatan ini merupakan kebutuhan yang berlangsung terus-menerus, karena kebutuhan ini akan kembali pada titik nol setelah dipenuhi. (b). Motivation Factors adalah faktor motivator yang menyangkut kebutuhan psikologis seseorang yaitu perasaan sempurna dalam melakukan pekerjaan. Faktor motivasi ini berhubungan dengan penghargaan terhadap pribadi yang berkaitan langsung dengan pekerjaan.

Cropley, (1985), menjelaskan motivasi sebagai "tujuan yang ingin dicapai melalui perilaku tertentu". Jadi motivasi kerja akan mendorong semangat kerja yang dapat memengaruhi komitmen terhadap organisasi. Dalam penelitian Gandari (2014) ditemukan pengaruh yang positif dan signifikan antara motivasi kerja terhadap komitmen pegawai dalam organisasi. Begitu juga dengan penelitian yang dilakukan oleh Buraidah., dan Lieke, (2012), yang membuktikan bahwa motivasi kerja dapat memengaruhi komitmen organisasi. Peningkatan komitmen organisasi merupakan suatu hal yang sangat penting bagi motivasi dan kualitas pegawai yang bekerja pada organisasi publik.

Pemerintah Provinsi NTB khususnya pada kantor Gubernur Provinsi NTB memerlukan kemampuan komitmen pegawai yang akan memengaruhi perilaku pelaksanaan tugas maupun hasil yang dicapai. Namun komitmen pegawai terhadap organisasi tidak ditunjukan oleh sebagian pegawai kantor Gubernur Provinsi NTB dengan mengabdikan diri pada organisasi karena secara rasional, pegawai kantor Gubernur Provinsi NTB merasa organisasi hanya bermanfaat bagi kebutuhan ekonomi dalam kehidupan. Berdasarkan pengamatan yang dilakukan, Komitmen pegawai kantor Gubernur Provinsi NTB dirasakan rendah, hal ini ditunjukkan oleh sikap beberapa pegawai yang ada pada kantor Gubernur Provinsi NTB seperti masih kurangnya loyalitas terhadap organisasi yaitu salah satunya disiplin waktu yang tergambar saat pimpinan dijadwalkan urusan dinas diluar daerah, beberapa pegawai enggan datang tepat waktu. 


\section{$J M M$ UNRAM \\ JURNAL MAGISTER MANAJEMEN UNIVERSITAS MATARAM \\ Maret 2016}

Artinya ketika ada pimpinan para pegawai disiplin tepat waktu. Kemudian hal lain yang terkait dengan tingkat komitmen pegawai kantor Gubernur Provinsi NTB pada organisasi yaitu tentang penyelesaiaan tugas dalam pekerjaan seperti penyelesaian laporan rutin bulanan yang masih terlihat belum tepat waktu.

Sebagian pegawai sudah menjalankan pekerjaan yang didelegasikan sesuai dengan tupoksinya masing-masing secara baik dan benar, namun masih ada sebagian lainnya yang belum menjalankan pekerjaannya dengan baik karena kompleksitas pekerjaan, disinilah keunikan karakteristik pekerjaan yang ada di kantor Gubernur Provinsi NTB, sehingga banyak sekali pegawai tidak dapat menyelesaikan pekerjaan tepat waktu pada bidang pekerjaan, seperti pengumpulan laporan tiap bulan yang sering kali terlambat. Disaat laporan akan di pertanggung jawabkan yaitu dalam penyelesaian laporan, pegawai mengulur waktu dengan menambah waktu yang sudah ditentukan oleh organisasi dalam penyelesaian laporan rutin dalam pekerjaannya. Serta beberapa pegawai juga enggan menerima tugas tambahan yang akan dikerjakan. Ini ditunjukkan pegawai melalui perilaku yaitu suka mengeluh kepada rekan kerja jika ada penambahan tipe tugas yang dibebankan kepadanya. Terindikasi kondisi ini menandakan bahwa komitmen pegawai masih rendah terlihat kurangnya disiplin waktu dan belum optimalnya usaha keras untuk membantu kesuksesan organisasi, dimana semua tipe tugas yang dibebankan kepadanya belum optimal.

Kantor Gubernur Provinsi NTB memiliki sejumlah pegawai yang dapat menunjang kinerja dalam organisasi sebanyak 500 orang yang merupakan aparatur negara (PNS) yang berada pada tujuh biro, yaitu pada Biro Hukum sebanyak 41 orang pegawai negeri sipil, Biro Organisasi sebanyak 47 orang pegawai negeri sipil, Biro Administrasi Perekonomian sebanyak 40 pegawai negeri sipil, Biro AP dan LPJP sebanyak 58 orang pegawai negeri sipil, Biro Kerjasama dan SDA sebanyak 36 orang pegawai negeri sipil, Biro Umum sebanyak 237 orang pegawai negeri sipil, dan Biro Kesra sebanyak 41 orang pegawai negeri sipil (sumber: data kepegawaian Setda Provinsi Nusa Tenggara Barat tahun 2014).

Berdasarkan hasil wawancara dengan beberapa pegawai pada kantor Gubernur Provinsi NTB terkait inspirasi mereka mengenai cara terbaik untuk melaksanakan tugas agar tepat waktu dan dapat diselesaikan dengan baik. Hal ini beberapa pegawai berpendapat, hal itu sulit dikarenakan beberapa faktor seperti karakteristik pekerjaan, lingkungan kerja dan motivasi kerja.

Karakteristik pekerjaan. Pegawai pada kantor Gubernur Provinsi NTB mempunyai banyak karakteristik pekerjaan terkait bidang pekerjaan, jabatan, kewenangan, suasana kerja, pengawasan, dan beban kerja di berbagai biro yaitu pada Biro Hukum, Biro Organisasi, Biro Administrasi Perekonomian, Biro AP dan LPJP, Biro Kerjasama dan SDA, Biro Umum, dan Biro Kesra. Bidang pekerjaan pegawai kantor Gubernur Provinsi NTB terdiri dari Bendahara Penerimaan, Bendahara Pengeluaran dan Bendahara Pengeluaran Pembantu yang bekerja untuk melaksanakan laporan kegiatan menerima, menyimpan, membayar atau menyerahkan, menatusahakan dan mempertanggungjawabkan uang dan surat berharga yang berada dalam pengelolaannya pada Kementerian Negara/Lembaga/ Kantor/Satuan.

Lingkungan kerja. Pada penelitian ini peneliti fokus pada lingkungan kerja fisik dikarenakan fenomena yang tergambar pada lingkungan kantor Gubernur Provinsi NTB terlihat ruang gerak didalam kantor yang belum memadai seperti di ruangan kerja, 


\section{$J M M$ UNRAM \\ JURNAL MAGISTER MANAJEMEN \\ UNIVERSITAS MATARAM \\ Maret 2016}

dimana ruang gerak yang saling berdekatan dengan ruangan rekan kerja disamping. Begitu juga pada ruangan kerja yang lain yaitu ruangannya digabung menjadi satu ruangan yang terdiri dari banyaknya pegawai yang akan bekerja di ruangan tersebut dan pelaksanaan rapat pun bisa dilakukan ditempat itu meskipun pegawai lain sedang bekerja di rungan tersebut. Serta adanya banyak berkas-berkas laporan yang menumpuk pada ruangan tersebut dan adanya beberapa AC yang rusak dan tidak berfungsi pada ruangan kerja di masing-masing tempat kerja pegawai. Hal lain terkait lingkungan kerja fisik yang dapat mengganggu aktivitas pegawai pada kantor Gubernur Provinsi NTB yaitu adanya tingkat kebisingan di suatu waktu dapat menggangu aktivitas kosentrasi para pegawai seperti kebisingan suara motor yang memakai resing melewati kantor Gubernur. Ini semua mengindikasikan bahwa lingkungan kerja fisik pada kantor Gubernur belum sepenuhnya memadai dalam mendukung aktivitas kerja yang dilakukan oleh pegawai kantor Gubernur Provinsi NTB.

Berdasarkan hasil pengamatan berikutnya mengenai motivasi kerja terlihat tingkat motivasi kerja pegawai kantor Gubernur NTB di katakan rendah, hal ini di tunjukkan oleh adanya faktor motivasi baik dalam dirinya maupun faktor motivasi eksternal. Motivasi dalam diri pegawai terlihat pekerjaan yang belum dapat diselesaikan tepat waktu sesuai target dari pimpinan, seperti pengerjaan laporan rutin bulanan. Namun, untuk memenuhi target tersebut, para pegawai harus bekerja ekstra sampai di luar jam kantor. Serta semangatnya dalam bekerja, seperti pada saat pimpinan ada di kantor para pegawai dengan semangatnya bekerja, namun disisi lain ketika pimpinan di luar daerah atau ada kepentingan dinas, para pegawai menunjukkan perilaku santai dalam bekerja. Selain itu terlihat beberapa pegawai melakukan sesuatu yang lebih baik dari rekan kerja, seperti menunjukkan dirinya yang paling dominan dalam semua hal terkait urusan pekerjaan. Belum adanya kesempatan untuk para pegawai untuk pengembangan diri dalam hal pekerjaan.

\subsection{Tujuan Penelitian}

a). Untuk mengetahui pengaruh signifikan dari karakteristik pekerjaan terhadap Komitmen Organisasi pada kantor Gubernur Provinsi NTB.

b). Untuk mengetahui pengaruh signifikan dari karakteristik pekerjaan terhadap Motivasi Kerja pegawai pada kantor Gubernur Provinsi NTB.

c). Untuk mengetahui pengaruh signifikan dari Lingkungan Kerja Fisik terhadap Komitmen Organisasi pada kantor Gubernur Provinsi NTB.

d). Untuk mengetahui pengaruh signifikan dari Lingkungan Kerja Fisik terhadap Motivasi Kerja pegawai kantor Gubernur Provinsi NTB.

e). Untuk mengetahui pengaruh signifikan dari motivasi kerja terhadap Komitmen Organisasi pada kantor Gubernur Provinsi NTB.

f). Untuk mengetahui pengaruh signifikan dari Karakteristik Pekerjaan terhadap Komitmen Organisasi melalui Motivasi Kerja pegawai.

g). Untuk mengetahui pengaruh signifikan dari Lingkungan Kerja Fisik terhadap Komitmen Organisasi melalui Motivasi Kerja pegawai pada kantor Gubernur Provinsi NTB. 


\section{TMM JURNAL MAgISTER MANAJEMEN UNIVERSITAS MATARAM \\ Maret 2016}

2. KAJIAN PUSTAKA

2.1. Penelitian Terdahulu

Buraidah., dan Lieke, E.M.W., (2012), melakukan penelitian tentang pengaruh kompensasi dan motivasi kerja terhadap komitmen organisasi. Hasil penelitian ada pengaruh signifikan kompensasi dan motivasi kerja terhadap komitmen organisasi.

Tania, A., dan Sutanto, E.M., (2013), melakukan penelitian tentang pengaruh motivasi kerja dan kepuasan kerja terhadap komitmen organisasi karyawan PT. Dai KNIFE di Surabaya. Hasil penelitian ada pengaruh motivasi kerja dan kepuasan kerja terhadap komitmen organisasi karyawan.

Maharani, R.D., (2009), melakukan penelitian tentang pengaruh kualitas kehidupan dan lingkungan kerja terhadap komitmen organisasi karyawan (Studi pada Divisi Peralatan Industri Argo PT. Barata Indonesia (Persero) Gresik). Hasil penelitian ada pengaruh kualitas kehidupan dan lingkungan kerja terhadap komitmen organisasi karyawan.

Subagyo, A., (2014), melakukan penelitian tentang pengaruh pengaruh lingkungan kerja dan self-efficacy terhadap komitmen organisasional Dosen Politeknik Negeri Semarang. Hasil penelitian ada pengaruh lingkungan kerja dan self-efficacy terhadap komitmen organisasional.

\subsection{Kajian Teori}

\subsubsection{Komitmen Organisasi} sebagai :

Kuntjoro (2002:27) berpendapat bahwa, komitmen organisasi sering didefinisikan

1. Keinginan yang kuat untuk tetap menjadi anggota organisasi tertentu.

2. Kemauan untuk melakukan usaha yang lebih besar untuk kepentingan organisasi.

3. Keyakinan yang pasti dan penerimaan terhadap nilai-nilai dan tujuan organisasi.

Luthans (2002:235) mendefinisikan komitmen organisasi dalam tiga pengertian, yakni sebagai (1) suatu kekuatan sikap sekaligus keputusan yang menjadi bagian organisasi, (2) suatu keinginan atau kehendak untuk mewujudkan kinerja tinggi sebagai bagian yang harus ditumbuhkembangkan dalam organisasi, dan sebagai (3) suatu keyakinan yang diterima sebagai value/nilai sekaligus tujuan yang harus dicapai oleh organisasi.

\subsubsection{Indikator Komitmen}

Berdasarkan tiga dimensi dari komitmen organisasioanal, maka dapat dirumuskan indikator atau pengukur dari masing-masing variabel sebagaimana yang dijelaskan berdasarkan pendapat Mowday, et.al (dalam Supriyono, 2005:46) yaitu:

1). Usaha keras yang secara normal diharapkan untuk membantu kesuksesan organisasi.

2). Merasa membanggakan kepada teman-teman bahwa organisasi adalah sebagai suatu organisasi yang hebat untuk bekerja. 


\section{TMM JURNAL MAGISTER MANAJEMEN UNIVERSITAS MATARAM

3). Bersedia menerima semua tipe tugas yang dibebankan kepada karyawan untuk terus bekerja demi organisasi.

4). Nilai-nilai yang ingin dicapai dengan nilai-nilai organisasi.

5). Bangga bagian dari organisasi.

6). Organisasi tempat kerja menimbulkan inspirasi mengenai cara-cara terbaik untuk melaksanakan tugas.

7). Senang memilih organisasi ini sebagai tempat kerja dibandingkan dengan organisasi lain.

8). Organisasi terbaik untuk bekerja dari pada semua organisasi lainnya.

9). Sungguh memperhatikan nasib organisasi.

Menurut Allen dan Meyer (Luthans, 2006) komitmen organisasi merefleksikan tiga komponen yaitu:

a). Affective commitment

Affective commitment adalah keterikatan emosional karyawan, identifikasi, dan keterlibatan dalam organisasi.

b). Continuance commitment

Continuance commitment adalah komitmen berdasarkan kerugian yang berhubungan dengan keluarnya karyawan dari organisasi. hal ini mungkin karena kehilangan senioritas atas promosi atau benefit.

c). Normative commitment

Normative commitment adanya perasaaan wajib untuk tetap berada dalam organisasi karena memang harus begitu; tindakan tersebut merupakan hal benar yang harus dilakukan.

Greenberg \& Baron (2000:182), bentuk-bentuk Komitmen Organisasi adalah:

a). Affective Commitment ialah kuatnya keinginan seseorang dalam bekerja bagi organisasi atau perusahaan disebabkan karena dia setuju dengan tujuan-tujuan organisasi tersebut dan ingin melakukannya.

b). Continuance Commitment ialah kuatnya keinginan seseorang dalam melanjutkan pekerjaannya bagi organisasi disebabkan karena dia membutuhkan pekerjaan tersebut dan tidak dapat melakukan pekerjaan yang lain.

c). Normative Commitment ialah kuatnya keinginan seseorang dalam melanjutkan pekerjaannya bagi organisasi disebabkan karena dia merasa berkewajiban dari orang lain untuk dipertahankan.

\subsubsection{Karakteristik Pekerjaan}

Menurut Hackman dan Oldham (1980:80) menyatakan bahwa: "Karakteristik pekerjaan adalah aspek internal dari suatu pekerjaan yang mengacu pada isi dan kondisi pekerjaan". Menurut Panggabean (2004:130) "Karakteristik pekerjaan berkaitan dengan pekerjaan itu sendiri dimana ia berkaitan dengan cara bagaimana karyawan menilai tugas-tugas yang ada dalam pekerjaannya".

Berry dan Houston (dalam Mundung, 2007) “Karakteristik pekerjaan adalah sikap aspek internal dari kerja itu sendiri yang terdiri dari variasi keterampilan yang 


\section{TMM JURNAL MAGISTER MANAJEMEN UNIVERSITAS MATARAM

dibutuhkan, prosedur dan kejelasan tugas, kewenangan dan tanggung jawab serta umpan balik dari tugas yang telah dilakukan.

\subsubsection{Indikator Karakteristik Pekerjaan}

Pada dasarnya setiap pekerjaan pasti mempunyai karakteristik sendiri-sendiri. Antara satu pekerjaan dengan pekerjaan yang lain dimungkinkan adanya kesamaan karakteristik namun dipastikan bahwa mayoritas pekerjaan mempunyai perbedaan karakteristik. Model karakteristik pekerjaan mengemukakan bahwa pekerjaan apa pun bisa dideskripsikan dalam lima dimensi pekerjaan utama, yaitu (Robbins, 2003:219) :

1). Keanekaragaman Keterampilan (Skill Variety)

Sejauh mana pekerjaan itu menuntut keragaman kegiatan yang berbeda sehingga pekerjaan itu dapat menggunakan sejumlah keterampilan dan bakat yang berbeda.

2). Identitas Tugas (Task Identity)

Sejauh mana pekerjaan itu menuntut diselesaikannya seluruh potongan kerja secara utuh dan dapat dikenali.

3). Arti Tugas (Task Significance)

Sejauh mana pekerjaan itu mempunyai dampak yang cukup besar pada kehidupan atau pekerjaan orang lain.

4). Otonomi (Autonomy)

Sejauh mana pekerjaan itu memberikan kebebasan, ketidaktergantungan, dan keleluasaan yang cukup besar kepada individu dalam menjadwalkan pekerjaan itu dan dalam menentukan prosedur yang digunakan dalam menyelesaikan pekerjaan itu.

5). Umpan Balik (Feedback)

Sejauh mana pelaksanaan kegiatan pekerjaan yang dituntut oleh pekerjaan itu menghasilkan diperolehnya informasi yang langsung dan jelas oleh individu mengenai keefektifan kinerjanya.

\subsubsection{Lingkungan Kerja Fisik}

Lingkungan fisik adalah sesuatu yang berada disekitar para pekerja yang meliputi cahaya, warna, udara, suara serta musik yang memengaruhi dirinya dalam menjalankan tugas-tugas yang dibebankan (Moekijat, 1995).

Sedarmayanti, (2001 dalam Hendri, 2012:4): Lingkungan kerja fisik adalah semua yang terdapat disekitar tempat kerja yang dapat memengaruhi pegawai baik secara langsung maupun tidak langsung. Sedangkan menurut Sarwono (2005 dalam Hendri, 2012:4) "Lingkungan kerja fisik adalah tempat kerja pegawai melakukan aktivitasnya". Lingkungan kerja fisik mempengaruhi semangat dan emosi kerja para karyawan. Faktorfaktor fisik ini mencakup suhu udara di tempat kerja, luas ruang kerja, kebisingan, kepadatan, dan kesesakan. Faktor-faktor fisik ini sangat mempengaruhi tingkah laku manusia. 
2.2.6. Indikator Lingkungan Kerja Fisik

Indikator lingkungan kerja menurut Sedarmayanti (2001:49-50) adalah sebagai berikut :

1. Penerangan/cahaya di tempat kerja

Cahaya atau penerangan sangat besar manfaatnya bagi karyawan guna mendapat keselamatan dan kelancaran kerja. Oleh sebab itu perlu diperhatikan adanya penerangan (cahaya) yang terang tetapi tidak menyilaukan. Cahaya yang kurang jelas, sehingga pekerjaan akan lambat, banyak mengalami kesalahan, dan pada skhirnya menyebabkan kurang efisien dalam melaksanakan pekerjaan, sehingga tujuan organisasi sulit dicapai.

2. Temperatur/suhu udara di tempat kerja

Dalam keadaan normal, tiap anggota tubuh manusia mempunyai temperatur berbeda. Tubuh manusia selalu berusaha untuk mempertahankan keadaan normal, dengan suatu sistem tubuh yang sempurna sehingga dapat menyesuaikan diri dengan perubahan yang terjadi di luar tubuh. Tetapi kemampuan untuk menyesuaikan diri tersebut ada batasnya, yaitu bahwa tubuh manusia masih dapat menyesuaikan dirinya dengan temperatur luar jika perubahan temperatur luar tubuh tidak lebih dari $20 \%$ untuk kondisi panas dan 35\% untuk kondisi dingin, dari keadaan normal tubuh.

3. Kebisingan di tempat kerja

Salah satu polusi yang cukup menyibukkan para pakar untuk mengatasinya adalah kebisingan, yaitu bunyi yang tidak dikehendaki oleh telinga. Tidak dikehendaki, karena terutama dalam jangka panjang bunyi tersebut dapat mengganggu ketenangan bekerja, merusak pendengaran, dan menimbulkan kesalahan komunikasi, bahkan menurut penelitian, kebisingan yang serius bisa menyebabkan kematian. Karena pekerjaan membutuhkan konsentrasi, maka suara bising hendaknya dihindarkan agar pelaksanaan pekerjaan dapat dilakukan dengan efisien sehingga produktivitas kerja meningkat.

4. Tata warna di tempat kerja

Menata warna di tempat kerja perlu dipelajari dan direncanakan dengan sebaik-baiknya. Pada kenyataannya tata warna tidak dapat dipisahkan dengan penataan dekorasi. Hal ini dapat dimaklumi karena warna mempunyai pengaruh besar terhadap perasaan. Sifat dan pengaruh warna kadang-kadang menimbulkan rasa senang, sedih, dan lain-lain, karena dalam sifat warna dapat merangsang perasaan manusia.

5. Ruang gerak yang diperlukan

Kondisi lingkungan yang baik adalah adanya ruang gerak di dalam lingkungan untuk mendukung aktivitas kerja para karyawan, misalnya adanya ruangan yang tidak sempit sehingga para karyawan nyaman dalam bekerja.

6. Keamanan di tempat kerja

Guna menjaga tempat dan kondisi lingkungan kerja tetap dalam keadaan aman maka perlu diperhatikan adanya keberadaannya. Salah satu upaya untuk menjaga keamanan di tempat kerja, dapat memanfaatkan tenaga Satuan Petugas Keamanan (SATPAM). 


\section{TMM JURNAL MAGISTER MANAJEMEN \\ UNIVERSITAS MATARAM \\ Maret 2016}

\subsubsection{Motivasi Kerja}

Menurut Heidjrachman dan Husnan (2011 : 197) menyatakan bahwa motivasi merupakan proses untuk mencoba memengaruhi seseorang agar melakukan sesuatu yang kita inginkan.

Motivasi adalah kesediaan yang dikondisikan oleh kemampuan upaya itu untuk memenuhi suatu kebutuhan individu (Robbins, 2003:166).

Sedangkan motivasi kerja adalah keinginan dan kesungguhan seseorang melakukan pekerjaannya dengan baik dan berdisiplin untuk mencapai prestasi kerja yang maksimal (Hasibuan, 2007: 94).

Menurut Rivai (2005:455), motivasi kerja adalah serangkaian sikap dan nilai-nilai yang memengaruhi individu untuk mencapai hal yang spesifik sesuai dengan tujuan individu. Sikap dan nilai tersebut merupakan suatu yang invisible yang memberikan kekuatan untuk mendorong individu bertingkah laku dalam mencapai tujuan. Sedangkan Marihot (2003:321), mengatakan bahwa motivasi adalah "Faktor-faktor yang mengarahkan dan mendorong perilaku atau keinginan seseorang untuk melakukan sesuatu kegiatan yang dinyatakan dalam bentuk usaha yang keras". Mathis (2001:89), mengatakan bahwa motivasi kerja adalah merupakan hasrat di dalam seseorang yang menyebabkan orang tersebut melakukan tindakan.

\subsubsection{Indikator Motivasi Kerja}

a). Variabel motivasi intrinsik diukur dengan indikator (menurut Robbins, 2006 dalam Akbar, 2012:11), yaitu :

1. Prestasi

Prestasi adalah pemberian kesempatan yang diberikan oleh perusahaan kepada karyawan yang berpotensi.

2. Penghargaan

Penghargaan adalah pemberian penghargaan kepada karyawan atas hasil kerja untuk mengembangkan diri.

3. Tanggung jawab

Tanggung jawab adalah tugas karyawan agar memahami dengan benar peran dan wewenang yang diberikan oleh perusahaan.

4. Pengembangan diri

Pengembangan diri adalah kesempatan kepada karyawan untuk maju dan berkembang dalam hal pekerjaan.

b). Variabel motivasi ekstrinsik diukur dengan indikator (menurut Robbins, 2006 dalam Akbar, 2012:11), yaitu :

1. Supervisi/pengawasan Supervisi/pengawasan adalah pengawasan dari atasan kepada karyawan.

2. Gaji

Gaji adalah besarnya imbalan yang diberikan kepada karyawan selain upah/gaji.

\section{Status}

Status adalah tingkat keberadaan sosial karyawan dalam pekerjaan. 


\section{TMM JURNAL MAGISTER MANAJEMEN UNIVERSITAS MATARAM \\ Maret 2016}

\subsection{Kerangka Konseptual}

Gambar 2.3. Kerangka Konseptual Penelitian

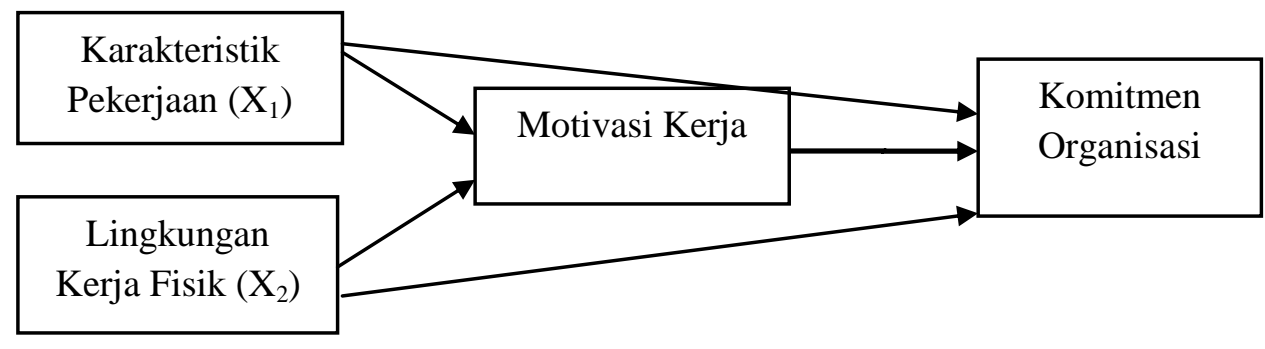

\subsection{Hipotesis Penelitian}

1). Diduga terdapat pengaruh yang positif signifikan Karakteristik Pekerjaan terhadap komitmen organisasi Pada Kantor Gubernur Provinsi NTB.

2). Diduga terdapat pengaruh yang positif signifikan Karakteristik Pekerjaan terhadap motivasi kerja pegawai Pada Kantor Gubernur Provinsi NTB.

3). Diduga terdapat pengaruh yang positif signifikan Lingkungan Kerja Fisik terhadap komitmen organisasi Pada Kantor Gubernur Provinsi NTB.

4). Diduga terdapat pengaruh yang positif signifikan Lingkungan Kerja Fisik terhadap motivasi kerja pegawai Pada Kantor Gubernur Provinsi NTB.

5). Diduga terdapat pengaruh yang positif signifikan motivasi kerja pegawai terhadap komitmen organisasi Pada Kantor Gubernur Provinsi NTB.

6). Diduga terdapat pengaruh yang positif signifikan karakteristik pekerjaan terhadap komitmen organisasi melalui motivasi kerja pegawai

7). Diduga terdapat pengaruh yang positif signifikan lingkungan kerja terhadap komitmen organisasi melalui motivasi kerja pegawai Pada Kantor Gubernur Provinsi NTB.

\section{METODE PENELITIAN}

Jenis penelitian lebih banyak mengacu pada rumusan masalah yang diangkat dan tujuan daripada penelitian.Jenis penelitian yang digunakan dalam penelitian ini adalah penelitian Asosiatif kausal (Sebab Akibat). Metode penelitian ini akan digunakan untuk mengetahui pengaruh Karakteristik Pekerjaan, Lingkungan Kerja Fisik dan Motivasi Kerja sebagai variabel intervening terhadap Komitmen Organisasi Pegawai Provinsi NTB.

\subsection{Populasi dan Sampel Penelitian}

\subsubsection{Populasi Penelitian}

Jumlah polusasi pegawai kantor Gubernur Provinsi NTB yang berjumlah 500 orang, yang merupakan pegawai negeri sipil.

\subsubsection{Responden Penelitian}

Sampel adalah bagian dari jumlah dan karakteristik yang dimiliki oleh populasi tersebut (Sugiyono, 2013:81). 
Jumlah sampel dalam penelitian ini ditentukan menggunakan rumus Slovin dari Taro Yamane (dalam Akdon dan Ridwan, 2006:249) yaitu :

$$
\begin{aligned}
& \mathrm{n}=\mathrm{N}:\left(\left(\mathrm{N} \times \mathrm{d}^{2}\right)+1\right) \text {, dimana : } \\
& \mathrm{n}=\text { Jumlah sampel } \\
& \mathrm{N}=\text { Jumlah populasi } \\
& \mathrm{d}^{2}=\text { Tingkat presisi atau akurasi yang ditetapkan }(=10 \%) .
\end{aligned}
$$

$$
n=\frac{500}{(500 \times 0,01)+1)} \quad n=\frac{500}{6}=83
$$

\subsection{Teknik dan Alat Pengumpulan Data}

Untuk memperoleh data yang representatif, baik data primer maupun data sekunder, maka dalam penelitian ini penulis menggunakan beberapa tehnik pengumpulan data sesuai dengan pendapat Sugiyono (2013 : 137-138), yaitu:

1). Wawancara, digunakan sebagai studi pendahuluan untuk menemukan permasalahan yang harus di teliti.

2). Angket, merupakan teknik pengumpulan data yang dilakukan dengan cara memberi seperangkat pertanyaan atau pernyataan tertulis kepada responden untuk dijawabnya.

3). Observasi, sebagai teknik pengumpulan data mempunyai ciri yang spesifik bila dibandingkan dengan teknik yang lain, yaitu wawancara dan kuesioner. Kalau wawancara dan kuesioner selalu berkomunikasi dengan orang lain, maka observasi tidak terbatas pada orang, tetapi juga obyek-obyek alam lainnya.

\subsection{Definisi Operasional Variabel}

1). Karakteristik Pekerjaan $\left(X_{1}\right)$ adalah persepsi responden tentang jumlah pekerjaan di dalam organisasi yang merupakan model atau pendekatan dari suatu tindakan dalam merancang pekerjaan.

Adapun idikatornya berdasarkan pendapat Robbins (2003), yaitu:
a. Keanekaragaman Keterampilan
b. Identitas tugas
c. Arti tugas
d. Otonomi
e. Umpan balik pekerjaan

2). Lingkungan Kerja $\operatorname{Fisik}\left(X_{2}\right)$ adalah persepsi responden tentang keadaan dan suasana lingkungan kerja disekitar pegawai pada saat bekerja yang berkaitan dengan bentuk fisik kantor Gubernur Provinsi NTB yang dapat memengaruhi pegawai pada saat menjalankan tugas yang diemban.

Adapun idikatornya berdasarkan pendapat Sedarmayanti (2001), yaitu:
a. Penerangan/cahaya di tempat kerja
b. Temperatur/suhu udara di tempat kerja
c. Kebisingan di tempat kerja
d. Tata warna di tempat kerja
e. Ruang gerak yang diperlukan
f. Keamanan di tempat kerja 
3). Motivasi $\operatorname{Kerja}(Z)$ adalah persepsi responden mengenai sikap yang terbentuk dalam diri dan di luar yang mendasari adanya kemauan responden untuk bekerja samadalam mencapai tujuan organisasi.

Adapun idikatornya berdasarkan pendapat (Robbins,2006 dalam Akbar, 2012), yaitu :

a. Motivasi intrinsik

b. Motivasi ekstrinsik

4). Komitmen Organisasi $(\mathrm{Y})$ adalah persepsi responden terhadap sikap terhadap organisasi yang menunjukkan responden sangat memikirkan dan mengutamakan pekerjaan dan organisasinya.

Adapun idikatornya berdasarkan pendapat Allen dan Meyer (dalam Luthans, 2006), yaitu :
a. Affective commitment
b. Continuance commitment
c. Normative commitment

\subsection{Path Tehnik Analisis}

Teknik analisis yang dipergunakan dalam penelitian ini adalah analisis jalur (Path Analysis), adapun langkah-langkahnya menurut Solimun (2002 : 47-55) adalah sebagai berikut:

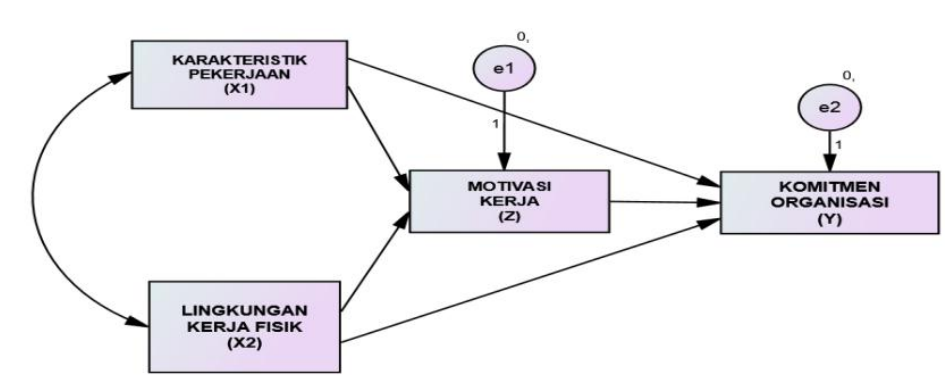

\section{Gambar 1. Model Penelitian}

Dalam analisis path model dirancang berdasarkan kerangka konseptual penelitian, rumusannya sebagai berikut:
a). Karakteristik pekerjaan mempunyai pengaruh yang signifikan terhadap motivasi kerja.
b). Lingkungan kerja fisik mempunyai pengaruh yang signifikan terhadap motivasi kerja.
c). Karakteristik pekerjaan mempunyai pengaruh yang signifikan terhadap komitmen organisasional.


d). Lingkungan kerja fisik mempunyai pengaruh yang signifikan terhadap komitmen organisasional.

e). Motivasi kerja mempunyai pengaruh yang signifikan terhadap komitmen organisasional

Berdasarkan hubungan antar variabel di atas, model matematika, menjadi sebagai berikut:
a) $Z=\gamma_{1.1} X_{1}+\varepsilon_{1}$
b) $Z=\gamma_{1.2} X_{2}+\varepsilon_{1}$
c) $Y=\gamma_{2.1} X_{1}+\varepsilon_{2}$
d) $Y=\gamma_{2.2} X_{2}+\varepsilon_{2}$
e) $\mathrm{Y}=\beta_{1} \mathrm{Z}+\varepsilon_{2}$
Atau:
a) Motivasi kerja $=\gamma_{1.1}$ Karakteristik pekerjaan $+\varepsilon_{1}$
b) Motivasi kerja $=\gamma_{1.2}$ Lingkungan kerja fisik $+\varepsilon_{1}$
c) Komitmen organisasional $=\gamma_{2.1}$ Karakteristik pekerjaan $+\varepsilon_{2}$
d) Komitmen organisasional $=\gamma_{2.2}$ Lingkungan kerja fisik $+\varepsilon_{2}$
e) Komitmen organisasional $=\beta$ Motivasi kerja $+\varepsilon_{2}$

\section{HASIL DAN PEMBAHASAN}

Padapenelitian ini dilakukan di kantor Gubernur Provinsi Nusa Tenggara Barat yang beralamat di Jl. Pejanggik No. 12 Mataram, Nusa Tenggara Barat. Penelitian ini fokus pada Pegawai Negeri Sipil yang berada pada tujuh biro, yaitu pada Biro Hukum sebanyak 41 orang pegawai negeri sipil, Biro Organisasi sebanyak 47 orang pegawai negeri sipil, Biro Administrasi Perekonomian sebanyak 40 pegawai negeri sipil, Biro AP dan LPJP sebanyak 58 orang pegawai negeri sipil, Biro Kerjasama dan SDA sebanyak 36 orang pegawai negeri sipil, Biro Umum sebanyak 237 orang pegawai negeri sipil, dan Biro Kesra sebanyak 41 orang pegawai negeri sipil.

\subsubsection{Pengaruh Karakteristik Pekerjaan terhadap Komitmen Organisasi Pada Kantor Gubernur Provinsi NTB.}

Hasil uji hipotesis bahwa terdapat pengaruh yang positif dan signifikan dari Karakteristik Pekerjaan terhadapKomitmen Organisasi pegawai kantor Gubernur Provinsi NTB.

Hasil penelitian ini didukung oleh penelitian yang dilakukan oleh Astuti, Subagyo, dan Adriyanto (2011), membuktikan bahwa karakteristik pekerjan berpengaruh terhadap komitmen organisasi.

Dari penelitian ini indikator-indikator yang digunakan yaitu :Keanekaragaman Keterampilan, Identitas tugas, Arti tugas, Otonomi dan Umpan balik pekerjaan.Jadi karakteristik pekerjaan seperti Keanekaragaman Keterampilan, Identitas tugas, Arti tugas, Otonomi dan Umpan balik pekerjaan menurut Munandar (dalam Moekijat 2003) Lima ciri-ciri intrinsik pekerjaan yang memperlihatkan 
kaitannya dengan komitmen organisasi untuk berbagai macam pekerjaan. Setiap dimensi inti dari pekerjaan mencakup aspek besar materi pekerjaan yang dapat mempengaruhi kepuasan kerja seseorang, semakin besarnya keragaman aktivitas pekerjaan yang dilakukan maka seseorang akan merasa pekerjaannya semakin berarti. Apabila seseorang melakukan pekerjaan yang sama, sederhana dan berulangulang maka akan menyebabkan rasa kejenuhan atau kebosanan. Kelima karakteristik kerja ini akan memengaruhi tiga keadaan psikologis yang penting bagi karyawan, yaitu: keberartian tugas, tanggung jawab, dan pengetahuan akan hasil kerja. Akhirnya, ketiga kondisi psikologis ini akan memengaruhi motivasi secara internal, kualitas kerja, serta kepuasan kerja karyawan (Mathis dan Jacson 2006).

Penelitian yang lakukan oleh Wirawati (2009), menyimpulkan bahwa faktor karakteristik pekerjaan berpengaruh signifikan secara parsial dan simultan terhadap kepuasan kerja karyawan PT. Kasmil Kosmos Bali.

Sedangkan menurut David (dalam Miner, 1997) oleh Sopiah (2008:163) mengemukakan empat faktor yang memengaruhi komitmen karyawan pada organisasi, salah satu faktornya yaitu karakteristik pekerjaan, misalnya: lingkup jabatan, tantangan dalam pekerjaan, konflik peran dalam pekerjaan, tingkat kesulitan dalam pekerjaan.

\subsubsection{Pengaruh Karakteristik Pekerjaan terhadap Motivasi Kerja pegawai Pada Kantor Gubernur Provinsi NTB.}

Hasil uji hipotesis bahwa terdapat pengaruh yang positif dan signifikan dari Karakteristik Pekerjaan terhadapMotivasi Kerja pegawai kantor Gubernur Provinsi NTB. Penelitian ini di dukung oleh penelitian yang dilakukan oleh Setiawan, A., Bodroastuti, T., (2012), dan Subyantoro, A., (2009), dimana hasil penelitian ini membuktikan bahwa secara empiris karakteristik pekerjaan berpengaruh terhadap motivasi kerja. Menurut Stoner dan Freeman, 1994 (dalam Subyantoro, 2099:12) menyatakan bahwa karakteristik pekerjaan merupakan sifat dari tugas yang meliputi tanggung jawab, macam tugas dan tingkat kepuasan yang diperoleh dari pekerjaan itu sendiri.Pekerjaan yang secara instrinsik memberikan kepuasan dan lebih memotivasi bagi kebanyakan orang dari pada pekerjaan yang tidak memuaskan.Sedangkan Menurut McCelland (dalam Suwatno dan Priansa, (2011:178) karakteristik orang yang berprestasi tinggi (high achievers) memiliki tiga ciri umum yaitu : a). sebuah preverensi untuk mengerjakan tugas-tugas dengan derajat kesulitan moderat. b). menyukai situasi-situasi dimana kinerja mereka timbul karena upaya-upaya mereka sendiri, dan bukan karena faktor-faktor lain, seperti kemujuran misalnya; dan c). menginginkan umpan balik tentang keberhasilan dan kegagalan mereka, dibandingkan dengan mereka yang berprestasi rendah.

\subsubsection{Pengaruh Lingkungan Kerja Fisik terhadap Komitmen Organisasi Pada Kantor Gubernur Provinsi NTB.}

Hasi penelitian membuktikan ada pengaruh yang positif dansignifikan dari Lingkungan Kerja Fisik terhadapKomitmen Organisasi. Penelitian ini di dukung oleh penelitian yang dilakukan oleh Maharani, R.D., (2009), dan Subagyo, A., (2014), 
dimana hasil penelitian ini membuktikan bahwa secara empiris lingkungan kerja fisik berpengaruh terhadap komitmen organisasi. Menurut Atkinson dan Hilgard (dalam Dewi, 2008) bahwa faktor-faktor yang memengaruhi komitmen organisasi salah satunya yaitu syarat-syarat fisik pekerjaan yang diinginkan, yaitu faktor fisik lingkungan atau segala sesuatu yang ada disekitar para pekerja dan yang dapat memengaruhi dirinya dalam menjalankan tugas. Lingkungan kerja yang kondusif akan menghadirkan suasana nyaman dalam menjalankan rutinitas sehari-hari. Karyawan merasa betah dan akan lebih berkomitmen dengan tempat kerjanya. Hal ini didukung oleh pendampat Armstrong (1999: 183), menurutnya ada tiga hal yang dipandang dapat memengaruhi komitmen organisasi, yaitu rasa memiliki terhadap organisasi, rasa senang terhadap pekerjaan, dan kepercayaan pada organisasi.Karakteristik keluarga, faktor harapan pengembangan karir, lingkungan kerja, dan gaji/tunjangan juga turut memengaruhi komitmen terhadap organisasi. Serta pendapat Susanto (1997:35) yang mengemukakan bahwa faktor yang dapat mendukung terciptanya psychological commitment adalah: karakteristik pekerjaan, komunikasi interaktif, sistem reward, lingkungan kerja, dan sistem pengembangan sumberdaya manusia.

\subsubsection{Pengaruh Lingkungan Kerja Fisik terhadap Motivasi Kerja pegawai Pada Kantor Gubernur Provinsi NTB.}

Hasil uji hipotesis menunjukkan bahwa terdapat pengaruh yang positif dan signifikan dari Lingkungan Kerja Fisik terhadapMotivasi Kerja pegawai kantor Gubernur Provinsi NTB.

Penelitian ini di dukung oleh penelitian yang dilakukan oleh Azhari, Z., dan Syamsir., (2014), Setyadi, B., Utami, H.N., dan Nurtjahjono, G.E., (2015), dimana hasil penelitian ini membuktikan bahwa secara empiris lingkungan kerja fisik berpengaruh terhadap motivasi kerja.Lingkungan kerja dapat meningkatkan motivasi kerja pegawai, lingkungan kerja yang nyaman baik tata letak dan bentuk lingkungan fisik yang memadai dapat memengaruhi tingginya motivasi kerja para pegawai.Menurut Sarwono (2005 dalam Hendri, 2012:4) "Lingkungan kerja fisik adalah tempat kerja pegawai melakukan aktivitasnya". Lingkungan kerja fisik memengaruhi semangat dan emosi kerja para karyawan.Faktor-faktor fisik ini mencakup suhu udara di tempat kerja, luas ruang kerja, kebisingan, kepadatan, dan kesesakan.Faktor-faktor fisik ini sangat memengaruhi tingkah laku manusia.Menurut Basuki \& Susilowati (2005 dalam Sanny dan Kristianti, 2012:63) apabila lingkungan kerja meningkat, maka semangat kerja juga akan meningkat.

Motivasi merupakan sebuah alasan atau dorongan seseorang untuk bertindak.Orang yang tidak mau bertindak sering kali disebut tidak memiliki motivasi.Alasan atau dorongan itu bisa datang dari luar maupun dari dalam diri.Dalam hubungannya dengan lingkungan kerja, McCormick (dalam Mangkunegara, 2002:64) mengemukakan bahwa motivasi kerja didefinisikan sebagai kondisi yang berpengaruh membangkitkan, mengarahkan dan memelihara perilaku yang berhubungan dengan lingkungan kerja. 


\subsubsection{Pengaruh Motivasi Kerja pegawai terhadap Komitmen Organisasi Pada Kantor Gubernur Provinsi NTB.}

Hasil uji hipotesis membuktikan terdapat pengaruh yang positif dan signifikan dari Motivasi Kerja terhadapKomitmen Organisasi.

Hasil penelitian ini didukung oleh penelitian yang dilakukan olehBuraidah., dan Lieke, E.M.W., (2012), Tania, A., dan Sutanto, E.M., (2013), Gandari, G., (2014), Astuti, S.D., Subagyo, H., dan Adriyanto, Y., (2011), dimana hasil penelitian ini membuktikan bahwa motivasi kerja berpengaruh signifikan terhadap komitmen organisasi.

Berbagai pandangan telah menguraikan bahwamotivasi mendorong munculnyaperilaku.Motivasi ada karena adanyakebutuhan dalam individu yang harus dipenuhi.Motivasi merupakan intensidari perilaku (Ibnu Umar, 1994 dalam Buraidah, 2012:2).Sebagai intensi dari perilaku makaperilaku yang muncul sesuai denganmotivasi yang ada.Dengan demikiandapat dikatakan bahwa motivasi kerjasangat diperlukan untuk memunculkanperilaku bekerja.Menurut Gibson dan Donelly (alih bahasa Djakarsih, 2007:103), motivasi adalah kekuatan dalam diri seseorang yang mampu mendorongnya melakukan sesuatu yang menimbulkan dan mengarahkan perilaku.

Siagian (2001:102) mendefinisikan motivasi adalah daya dorong bagi seorang untuk memberikan kontribusi yang sebesar mungkin demi keberhasilan organisasi mencapai tujuannya.Sopiah, (2008:159) berpendapat bahwa dalam proses terjadinya komitmen organisasi yaitu diantaranya adalah membangun nilai-nilai yang berdasarkan adanya kesamaan. Setiap anggota organisasi memiliki kesempatan yang sama, misalnya untuk promosi maka dasar yang digunakan untuk promosi adalah kemampuan, keterampilan, minat, motivasi, kinerja, tanpa ada diskriminasi. Dengan demikian motivasi mempunyai hubungan yang penting dengan komitmen organisasi, motivasi merupakan salah satu aspek proses terjadinya komitmen organisasi.

\subsubsection{Pengaruh Karakteristik Pekerjaan terhadap Komitmen Organisasi melalui Motivasi Kerja pegawai Pada Kantor Gubernur Provinsi NTB.}

Hasi uji hipotesis membuktikan terdapat pengaruh yang positif dan signifikan dari Karakteristik Pekerjaan terhadap Komitmen Organisasi melalui Motivasi Kerja.

Pada dasarnya Karakteristik Pekerjaan terhadap Komitmen Organisasi terbukti bahwa terdapat pengaruh yang positif namun tidak signifikan dariKarakteristik Pekerjaan terhadap Komitmen Organisasi.Karakteristik Pekerjaan terhadapKomitmen Organisasi dapat berpengaruh signifikan apabila melalui Motivasi Kerja sehingga menciptakan Kepuasan Kerja Pegawai Kantor Gubernur Provinsi NTB. Temuan ini dapat di lihat dari hasil penelitian yang menunjukkan bahwa secara umum persepsi responden mengenai sikap yang terbentuk dalam diri dan di luar yang mendasari adanya kemauan responden untuk bekerja sama dalam mencapai tujuan organisasi di tunjukkan adanya motivasi kerja yang tinggi seperti adanya adanya dorongan dalam diri pegawai yang selalu bekerja secara maksimal 
agar memperoleh prestasi kerja di dalam organisasi, ini merupakan kemauan dan dorongan diri sendiri untuk mencapai target dengan baik dalam memperoleh prestasi kerja dengan menunjukan bekerja dengan sebaik mungkin dan bertanggung jawab atas pekerjaan. Serta menyelesaikan pekerjaan dengan tuntas tanpa adanya penundaan, dimana para pegawai beranggapan bahwa mereka senang bekerja untuk selalu mengembangkan potensi yang ada pada dirinya.Hal ini semua para pegawai lakukan supaya selalu adanya pengakuan yaitu status sebagai pegawai di Kantor Gubernur Provinsi NTB.Artinyamotivasi merupakan proses untuk mencoba memengaruhi seseorang agar melakukan sesuatu yang yang diinginkan, seperti adanya pengaruh dari motivasi intrinsik dan ekstrinsik yang ada di kantor Gubernur Provinsi NTB.

\subsubsection{Pengaruh Lingkungan Kerja terhadap Komitmen Organisasi melalui} Motivasi Kerja pegawai Pada Kantor Gubernur Provinsi NTB.

Hasil uji hipotesis membuktikan bahwa terdapat pengaruh yang positif dan signifikan dari Lingkungan Kerja Fisik terhadapKomitmen Organisasi melalui Motivasi Kerja pada kantor Gubernur Provinsi NTB.

Lingkungan kerja yang ada di kantor Gubernur Provinsi NTB menggambarkan keadaan yang baik, dimana para pegawai bekerja dengan suasana nyaman ini terlihat motivasi kerja para pegawai kantor Gubernur Provinsi NTB motivasi tinggi. Hasil penelitian ini menunjukkan bahwa secara umum persepsi responden mengenai sikap yang terbentuk dalam diri dan di luar yang mendasari adanya kemauan responden untuk bekerja sama dalam mencapai tujuan organisasi di tunjukkan adanya motivasi kerja yang tinggi seperti adanya adanya dorongan dalam diri pegawai yang selalu bekerja secara maksimal agar memperoleh prestasi kerja di dalam organisasi, ini merupakan kemauan dan dorongan diri sendiri untuk mencapai target dengan baik dalam memperoleh prestasi kerja dengan menunjukan bekerja dengan sebaik mungkin dan bertanggung jawab atas pekerjaan. Serta menyelesaikan pekerjaan dengan tuntas tanpa adanya penundaan, dimana para pegawai beranggapan bahwa mereka senang bekerja untuk selalu mengembangkan potensi yang ada pada dirinya.Hal ini semua para pegawai lakukan supaya selalu adanya pengakuan yaitu status sebagai pegawai di Kantor Gubernur Provinsi NTB.

Dari adanya lingkungan kerja yang memadai, serta timbulnya motivasi kerja dapat meningkatkan komitmen para pegawai pada kantor Gubernur Provinsi NTB. Ini terlihatpun bentuk komitmen para pegawai yaitu terlihat bahwa pegawai mempunyai komitmen yang tiggi kepada organisasi, ini terlihat bahwa pegawai sangat bahagia menghabiskan sisa karirnya pada kantor Gubernur Provinsi NTB, dimana para pegawai beranggapan bahwa organisasi ini memiliki arti yang sangat besar bagi pegawai dan merasa terikat secara emosional pada organisasi saat ini dan para pegawai merasa menjadi bagian dari keluarga pada organisasi ini. 


\section{KESIMPULAN DAN SARAN}

5.1. Kesimpulan

1). Terdapat pengaruh yang positif dan signifikan Karakteristik Pekerjaan terhadap komitmen organisasi Pada Kantor Gubernur Provinsi NTB.

2). Terdapat pengaruh yang positif signifikan Karakteristik Pekerjaan terhadap motivasi kerja pegawai Pada Kantor Gubernur Provinsi NTB.

3). Terdapat pengaruh yang positif signifikan Lingkungan Kerja Fisik terhadap komitmen organisasi Pada Kantor Gubernur Provinsi NTB.

4). Terdapat pengaruh yang positif signifikan Lingkungan Kerja Fisik terhadap motivasi kerja pegawai Pada Kantor Gubernur Provinsi NTB.

5). Terdapat pengaruh yang positif signifikan motivasi kerja fisik pegawai terhadap komitmen organisasi Pada Kantor Gubernur Provinsi NTB.

6). Terdapat pengaruh yang positif signifikan karakteristik pekerjaan terhadap komitmen organisasi melalui motivasi kerja pegawai.

7). Terdapat pengaruh yang positif signifikan lingkungan kerja fisik terhadap komitmen organisasi melalui motivasi kerja pegawai Pada Kantor Gubernur Provinsi NTB.

\subsection{Saran}

1). Hasil penelitian terbukti bahwa karakteristik pekerjaan dapat memengaruhi komitmen pegawai dalam organisasi apabila terlebih dahulu dapat meningkatkan motivasi kerja pegawai baik dalam diri individu maupun eksternal, hal ini dapat meningkatkan komitmen pegawai.

Hal yang dapat ditingkatkan lagi terkait karakteristik pekerjaan yang ada pada kantor Gubernur Provinsi NTB yang terlihat bahwa pegawai bertindak secara mandiri dari atasan dalam melaksanakan pekerjaan. Hasil penelitian ini perlu di perhatikan oleh pimpinan agar pekerjaan yang dikerjakan oleh para pegawai dapat meningkatkan komitmen terhadap organisasi. Dimana hasil penelitian karakteristik dapat berpengaruh signifikan jika adanya motivasi terlebih dahulu, baik motivasi dalam diri maupun eksternal.

2). Bagi peneliti selanjutnya disarankan untuk memilih subjek penelitian dengan mempertimbangkan indikator dalam variabel yang akan digunakan seperti karakteristik pekerjaan dan memperhatikan variabel-variabel lain yang berpengaruh terhadap komitmen organisasiserta motivasi kerja. Selain itu juga disarankan untuk penelitian selanjutnya dapat diperdalam terhadap penggunaan kuesioner, mengingat masih banyaknya keterbatasan dalam penelitian ini. 


\section{TMM JURNAL MAGISTER MANAJEMEN \\ UNIVERSITAS MATARAM \\ Maret 2016}

\section{DAFTAR PUSTAKA}

Arnie., Ariefqi., dan Manick.., 2011, "Pentingnya SDM Dalam Sebuah Organisasi". Artikel. Diakses tanggal 04 November 2015. Tersedia di http://arnie0307. blogspot.co.id/2011/11/pentingnya-sdm-dalam-sebuah-organisasi.html.

Akdon., dan Ridwan., 2006. Aplikasi Statistika dan Metode Penelitian Untuk Administrasi dan Manajemen. Bandung : Dewa Ruci.

Astuti, S.D., Subagyo, H., dan Adriyanto, Y., (2011), "Pengaruh Karakteristik Pekerjaan Dan Motivasi Terhadap Komitmen Organisasional Serta Dampaknya Terhadap Kinerja Pegawai (Studi pada Balai Penelitian dan Pengembangan Agama Kementrian Agama)", Jurnal Manajemen Dan Bisnis, 15 (1) : pp17-28.

Allen , N, J. dan Meyer, I.P., 1990, "The Measurement and Antecedents of Affective, Continuance and Normative Commitment to Organization"e, Journal of Occupational Psychology. New york.

Buraidah., dan Lieke, E.M.W., 2012, Pengaruh Kompensasi Dan Motivasi Kerja Terhadap Komitmen Organisasi Di Organisasi Pendidikan Islam X, Jurnal Fakultas Ekonomi Universitas Guna Darma. Tersedia di http://www.gunadarma.ac.id/library/articles/postgraduate/psychology/Artikel 94104015.pdf. diakses tanggal 15 Februari 2015.

Berry, L.M. and Houston, J.P. 1993. Psychology at Work. An Introduction to Industrial and Organizational Psychology. New York: McGraw-Hill International.

Cropley, A.J, 1985, Motivation for Participation in Adult Education, edisi Motivation for Adult Education, J. H Knoll, Munchen : Saut.

Djastuti, I., (2011), "Pengaruh Karakteristik Pekerjaan Terhadap Komitmen Organisasi Karyawan Tingkat Managerial Perusahaan Jasa Konstruksi di Jawa Tengah. Jurnal Manajemen. Di akses tanggal 2 September 2015.

Greenberg, Jerald dan Baron, Robert A. 2000. Perilaku Organisasi. Jakarta : Prentice Hall

Gandari, G., (2014), "pengaruh motivasi kerja terhadap komitmen organisasi pegawai di Badan Perencanaan Pembangunan Daerah (BAPPEDA) Kabupaten Karang Tumaritis", Jurnal Manajemen. Di akses tanggal 1 September 2015.

Hackman, J.R., dan Oldham, G.R., (1980). Work Redesign. Reading. MA: Addison-Wesley.

Heidjrachman dan Suad Husnan, 2000, Manajemen Personalia, Edisi 4, Cetakan Kesembilan, BPFE, Yogyakarta

Hasibuan, M.S.P., (2007). Manajemen Sumber Daya Manusia, cetakan kesembilan, Jakarta : PT Bumi Aksara. 


\section{TMM JURNAL MAgISTER MANAJEMEN \\ UNIVERSITAS MATARAM \\ UNRAM \\ Maret 2016}

Kinicki, Angelo., And Kreitner, Robert., (2005). Perilaku Organisasi. Jakarta. Salemba empat

Kuntjoro, Z.S., 2002. Komitmen Organisasi. [on-line]. www.epsikologi.com/masalah/250702.htm.

Luthans, F., 2002. Performance and Motivation. New York: Prentice Hall.

.2006. Prilaku Organisasi. Penerbit Andi. Yogyakarta.

Mowday, R.T., Porter, L.W., \& Steers, R.M., 1982, Employee-organization linkages: The psychology of commitment, absenteeism, and turnover. New York: Academic Press.

Mathis, R. L., dan Jackson, J.H., 2001, Manajemen Sumber Daya Manusia, buku 1 dan buku 2, Terjemahan, Salemba Empat, Jakarta.

Marihot., 2003, Manajemen Sumber Daya Manusia, PT. Gramedia: Jakarta.

Mundung, M., (2007), “Pengaruh Karakteristik Kerja, Iklim Kerja dan Kompensasi terhadap Kepuasan Kerja Karyawan Wanita (Studi pada Perusahaan Ikan Kaleng "Joint Venture" di Kota Bitung)". Jurnal Ekonomi dan Manajemen, Volume 8 Nomor 1, Februari.

Maharani, R.D., (2009), “Pengaruh kualitas kehidupan dan lingkungan kerja terhadap komitmen organisasi karyawan (Studi pada Divisi Peralatan Industri Argo PT. Barata Indonesia (Persero) Gresik)". Jurnal Manajemen. Di akses tanggal 25 Juli 2015.

Meyer, J. P., \& Allen, N. J. 1997, Commitment in the worplace theory research and application. California: Sage Publications.

Moekijat. 1995. Manajemen Personalia dan Sumber Daya Manusia. CV. Mandar Maju. Bandung.

Panggabean, S., Mutiara. 2004. Manajemen Sumber Daya Manusia. Bogor: Ghalia Indonesia.

Robbins, S.P., 2003. Perilaku Organisasi, Jilid 2, PT. Indeks Kelompok Gramedia, Jakarta. ., (2006), Perilaku Organisasi, Jakarta : Indeks

Rivai, V., 2005, Kepemimpinan dan Perilaku Organisasi. Raja Grafindo: Jakarta.

Saputra, A.P., (2014), "Pengaruh Lingkungan Kerja dan Kepuasan Kerja Terhadap Komitmen Organisasional (Studi pada PT. Industri Sandang Nusantara (ISN) Unit Patal Lawang Malang). Jurnal Ekonomi. Di akses tanggal 29 September 2015. 


\section{TMM JURNAL MAGISTER MANAJEMEN UNIVERSITAS MATARAM UNRAM \\ Maret 2016}

Solimun. 2004. Structural Equation Modelling.Aplikasi Software Amos. FMIPA \& PPS Universitas Brawijaya, Malang

Sugiyono., 2013, Metode Penelitian Kuantitatif kualitatif dan RED. Bandung: Alfabeta.

Sarwono, Sarlito Wirawan, 2005, Psikologi Lingkungan, Penerbit PT. Gramedia Grasindo, Jakarta.

Sedarmayanti, (2001). Sumber Daya Manusia dan Produktivitas Kerja. Mandar Maju, Bandung.

Srimulyani, V.A., 2015, “Tipologi Anteseden Komitmen Organisasi”, Jurnal Manajemen Ekonomi, diakses tanggal 26 September 2015.

Sopiah., 2008., Perilaku Organisasi, Yogyakarta: Penerbit Andi.

Undang-Undang Republik Indonesia No. 8 Ta. 1974 tentang Pokok-Pokok Kepegawaian. Dia akses tanggal 18 Oktober 2015. Tersedia di http://sipuu.setkab.go.id/PUUdoc/4057/uu0081974.pdf

Wignjosoebroto,S., 2000. Ergonomi, Studi Gerak dan Waktu Teknik Analisis untuk Peningkatan Produktivitas Kerja. Edisi I cetakan Kedua, Penerbit Guna widya, Surabaya. 